\title{
COVID-19, Seignorage, Quantitative Easing and the Fiscal-Monetary Nexus
}

\author{
Alex Cukierman ${ }^{1}$ (D) \\ Accepted: 1 April 2021 / Published online: 13 April 2021 \\ (c) Association for Comparative Economic Studies 2021
}

\begin{abstract}
The huge fiscal expansions triggered by the corona crisis raised debt/GDP ratios to very high levels. This led some economists to reconsider the taboo on seignorage. Following a brief documentation of the crisis impact and aggregate demand policies responses the paper discusses views of academics and policymakers on seignorage. Optimal taxation considerations imply that the decision on allocating deficit financing between debt and seignorage falls within the realm of fiscal authorities - a fact that infringes on central bank (CB) autonomy. The paper explores ideas aimed at improving the tradeoff between those two principles. Implication of cross-country variations in the need to use seignorage is discussed. Comparison of the indirect contribution of quantitative easing (QE) to deficit financing with the direct contribution of seignorage implies that $\mathrm{QE}$ is a substitute to seignorage that preserves central bank dominance without much change in existing monetary institutions. Comparison of empirical evidence from the USA during the global financial crisis with the post-WWI German inflation supports the view that for countries experiencing deflationary pressure seignorage is more potent in moving inflation toward its target than QE. Given the current outlook temporary use of seignorage does not appear to involve a substantial risk of inflation.
\end{abstract}

Keywords COVID-19 - Seignorage · Deficits · Government debt · Optimal taxation · Central bank independence · Quantitative easing · Fiscal institutions · Inflation and deflation

JEL Classification E5 $\cdot \mathrm{E} 62 \cdot \mathrm{E} 63 \cdot \mathrm{E} 31 \cdot \mathrm{H} 21 \cdot \mathrm{H} 12 \cdot \mathrm{H} 6$

\footnotetext{
I benefited from the comments of 3 anonymous referees, from the reactions of participants at the virtual finance theory seminar at Ecole Polytechnique and from discussions with Assaf Razin and Efraim Sadka. The usual disclaimer applies.
}

\section{Alex Cukierman}

alexcuk@tauex.tau.ac.il

1 Interdisciplinary Center and CEPR, Tel-Aviv University, Tel Aviv-Yafo, Israel 


\section{Introduction}

The corona crisis is the most serious crisis since the great depression (GD). It was totally unanticipated leaving medical establishments unprepared in face of the COVID-19 virus. It is disrupting aggregate supply, aggregate demand and is inflicting painful arbitrary losses of income on large segments of consumers and businesses. Like the GD and the global financial crisis (GFC) of 2007/2009 it calls, among other, for substantially larger fiscal and monetary measures as well as tax relief.

Unlike the GD and the GFC whose origins were financial the origin of the corona crisis is on the real side creating a tradeoff between averting a plague and a major economic downturn. ${ }^{1}$ The initial absence of a vaccine, its slow administration to the public along with the emergence of new variants are still forcing most governments to severely limit social interactions leading to serious disruptions in employment, production, supply chains, and aggregate demand. Following their early success in reducing the number of new corona cases tight lockouts were subsequently replaced by less stringent sanitary measures. Unfortunately, as of March 2021 many countries have gone through additional waves of high virus infections.

Policymakers in most countries responded by deploying huge fiscal packages leading to large deficits and substantial increases in debt/GDP ratios. The huge financing needs triggered by those policies along with the tameness of inflation and the frequently reached zero lower bound (ZLB) on the policy rate led a number of economists to seriously consider temporary lifting of the existing taboo on seignorage financing of deficits by the central bank. Once seignorage is admitted as a legitimate source of deficit financing along with national debt, optimal taxation theory implies that the contribution of those two sources of funds should be determined by weighting the marginal distortions associated with each source of funds. Although under current institutions the $\mathrm{CB}$ has the sole authority to increase the monetary base, this is a task that is naturally within the realm of elected fiscal policymakers.

This raises the following non-trivial dilemma: How to implement an efficient use of seignorage during serious emergencies without opening the spigot for monetary financing of fiscal deficits during normal times. The paper considers possible solutions to this dilemma and the associated risks including the, currently remote, risk of inflation and of upward unanchoring of inflationary expectations.

The need to resort to seignorage varies across countries in line with their initial debt/GDP ratios and access to the bond market. Although seignorage is probably superfluous for countries with good credit ratings and relatively low debt/GDP ratios, it may be essential for heavily indebted countries with poor access to capital markets. The paper documents substantial variations in debt/GDP ratios across country groups and discusses the roles of differences in access to financial markets and in levels of development for the need to rely on seignorage.

\footnotetext{
1 A succinct early discussion of this tradeoff appears in Gourinchas (2020).
} 
There is an important technical similarity between $\mathrm{QE}$ and seignorage in that they both are implemented by creating new base money to buy government securities. The main difference between them is that under quantitative easing the $\mathrm{CB}$ is allowed to buy only seasoned government bonds to maintain price and financial stability. By contrast when seignorage is legal, the CB is allowed to buy new public securities at source in order to provide direct financing to government. Unlike QE each $\$$ of full impact seignorage contributes a full $\$$ toward deficit financing. ${ }^{2}$ Although smaller, the contribution of a $\$$ of QE to deficit finances is nonzero since it provides a deeper market for government securities lowering governmental debt service costs.

The paper organization follows. Section "Economic Impact of the Corona Crisis and the Response of Aggregate Demand Policies" briefly documents the economic impact of the COVID-19 virus and the response of aggregate demand policies. Section "Seignorage and the Role of CBs: Past and Present" discusses the views of economists and central bankers in the past and present on the use of seignorage during emergency periods. Section "Seignorage as a Source of Public Finance within the Theory of Optimal Taxation and the Tradeoff between Implementation of Optimal Taxation and Central Bank Autonomy" places seignorage within the theory of optimal taxation and explores some ideas aimed at improving the tradeoff between implementation of the optimal taxation principle and CB autonomy. Implication of cross-country variations in the need to use seignorage is discussed in section "Deployment of Fiscal Policies during the Corona Crisis and Cross-Country Variations in the Need to Use Seignorage". An implication of the discussion is that for governments with adequate access to capital markets seignorage may be superfluous but it is likely to be an essential temporary device for governments with limited access.

Seignorage and QE are compared in section "Seignorage versus Quantitative Easing (QE) and Central Bank Dominance". Two implication of this comparison is that (i) seignorage can be implemented temporarily under $\mathrm{CB}$ dominance without much change in existing institutions, (ii) sufficiently larger doses of QE can achieve results similar to those of one dose of seignorage. It is likely that, in spite of huge increases in Debt/GDP ratios, this is the implicit thinking underlying the decision of practically all advanced economies to rely on QE rather than break the taboo on monetary financing. Section "Should Seignorage be used in View of the Current Inflation Outlook?" evaluates the case for limited use of seignorage in light of the current inflation outlook. It notes that for groups of countries affected by deflation, such as the Euro area and Japan, some limited amount of seignorage is also beneficial because it is more effective than QE in generating inflation. Empirical evidence on the higher effectiveness of seignorage in raising inflation is provided by means of a comparison of substantial QE operations through base expansion practiced in the USA during the GFC with base expansion of the same size used for seignorage operations

\footnotetext{
${ }^{2}$ Full impact seignorage is defined as a perpetual zero interest loan by the CB to government. A fuller discussion appears in section "Seignorage and the Role of CBs: Past and Present."
} 
during part of the post-WWI German hyperinflation. This is followed by concluding remarks.

\section{Economic Impact of the Corona Crisis and the Response of Aggregate Demand Policies}

Unlike the GFC and the great depression the corona crisis originated in the real economy and was totally unanticipated. The initial absence of vaccines against the COVID-19 virus and its speedy contagiousness prompted medical and political authorities to curtail mobility by imposing lockdowns, quarantines, social distancing and an almost complete standstill of international air travel. By forcing large portions of the work force into segregation and closing down businesses this inevitable policy reaction transformed the impact of the virus from a pure medical emergency into a major real negative supply shock.

The appearance of vaccines raised hopes that the pandemic would be quickly contained. Unfortunately, as of March 2021 the slowness of the immunization process along with the appearance of new variants casts serious doubts on such an optimistic scenario and still forces governments to alternate between less and more stringent sanitary policies.

Reduction in mobility due to restrictions along with individually motivated measures against the pandemic led to a substantial shut down of the economy, reduced production, layoffs, income losses, disruption of supply chains, and elevated personal and aggregate uncertainty. Those effects were amplified by the universality of the medical cum economic crisis and the associated reduction, during 2020, in world trade. The actual and expected GDP shrinkages quickly spilled over to financial markets leading to credit restrictions and capital outflows from developing markets. Sectors relying on social interactions such as travel, entertainment, and tourism took a particularly heavy toll. In parallel international demand for producers of medical supplies soared. The drastic reduction in air and car travel along with production stoppages led, during 2020, to the collapse of the price of crude oil creating serious problems for government finances in some oil producing countries like Russia and Saudi Arabia. But during the first quarter of 2021 the price of oil as well as world trade partially recovered.

Table 1 shows actual rates of growth by major country groups and selected countries for 2019 and 2020. Except for China, all countries in the table have experienced negative rates of growth in 2020 reflecting the global reach of the virus and its economic ramifications. Rates of growth are more negative in advanced economies than in emerging markets and developing economies. Within advanced economies there are substantial differences in the adverse growth effects on GDP ranging from a minimum of -2.5 for other advanced economies to a maximum of -11.1 for Spain.

Although not uniform the response of fiscal and monetary policies over the world has been swift and unprecedented in size. Particularly striking is the over 2.2 trillion \$ CARES act that was passed at the end of March 2020 in the USA. Unprecedented in size and scope, the legislation was the largest-ever economic stimulus package in US history, amounting to $10 \%$ of total US gross domestic product. The bill was 
Table 1 Yearly rates of growth (year over year percentages). Source: IMF World Economic Outlook Update January (2021)

\begin{tabular}{|c|c|c|}
\hline & \multirow[b]{2}{*}{2019} & \multirow{2}{*}{$\frac{\text { Estimate }}{2020}$} \\
\hline & & \\
\hline World output & 2.8 & -3.5 \\
\hline Advanced economies & 1.6 & -4.9 \\
\hline USA & 2.2 & -3.4 \\
\hline Euro area & 1.3 & -7.2 \\
\hline Germany & 0.6 & -5.4 \\
\hline France & 1.5 & -9.0 \\
\hline Italy & 0.3 & -9.2 \\
\hline Spain & 2.0 & -11.1 \\
\hline Japan & 0.3 & -5.1 \\
\hline UK & 1.4 & -10.0 \\
\hline Canada & 1.9 & -5.5 \\
\hline Other advanced economies 3 / & 1.8 & -2.5 \\
\hline Emerging market and development economies & 3.6 & -2.4 \\
\hline Emerging and developing Asia & 5.4 & -1.1 \\
\hline China & 6.0 & 2.3 \\
\hline India 4/ & 4.2 & -8.0 \\
\hline ASEAN-5 5/ & 4.9 & -3.7 \\
\hline Emerging and development Europe & 2.2 & -2.8 \\
\hline Russia & 1.3 & -3.6 \\
\hline Latin America and the Caribbean & 0.2 & -7.4 \\
\hline Brazil & 1.4 & -4.5 \\
\hline Mexico & -0.1 & -8.5 \\
\hline Middle East and Central Asia & 1.4 & -3.2 \\
\hline Saudi Arabia & 0.3 & -3.9 \\
\hline Sub-Saharan Africa & 3.2 & -2.6 \\
\hline Nigeria & 2.2 & -3.2 \\
\hline South Africa & 0.2 & -7.5 \\
\hline \multicolumn{3}{|l|}{ Memorandum } \\
\hline Low-income developing countries & 5.3 & -0.8 \\
\hline World growth based on market exchange rates & 2.4 & -3.8 \\
\hline
\end{tabular}

3/ Excludes the group of seven (Canada, France, Germany, Italy, Japan, UK, USA) and Euro area countries

4/ For India data and forecasts are presented on a fiscal year basis and at market prices

5/ Indonesia, Malaysia, Phillipnes, Thailand, Vietnam

much larger than the $\$ 831$ billion stimulus act passed in 2009 as part of the response to the GFC. The bill provides health care funds, relief to business and organizations in the form of loans, tax credit, tax deferrals and deductions, relief to individuals in various forms such as tax rebates, unemployment benefits, student grants and loans as well as help to defense contractors. At the beginning of March 2021 a 1.9 


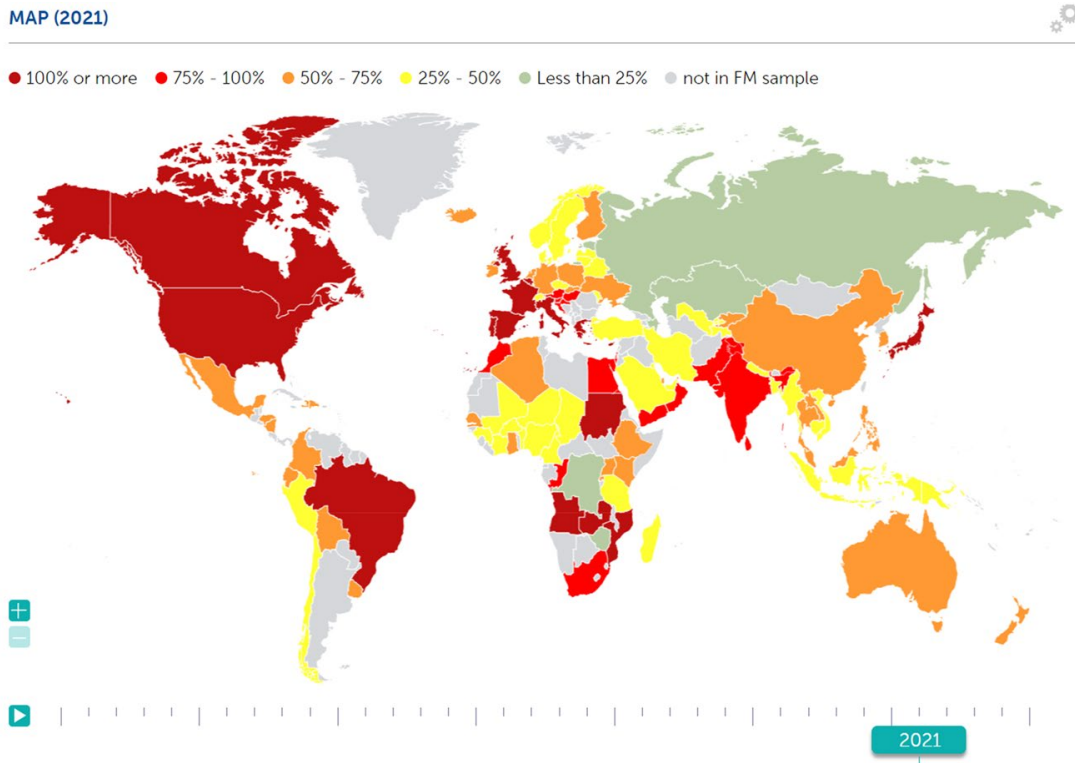

Source: IMF October 2020 Fiscal Monitor

Fig. 1 Map of gross debt positions as a share of GDP

trillion \$ Covid Relief Bill was signed into law by President Beiden. Although not as large as in developed economies unusually high fiscal expansions also took place in emerging markets and low-income developing countries. Detailed country information on fiscal responses to the Covid19 crisis appears in the IMF Data Base of Fiscal Policy Responses to Covid19 (2021).

The worldwide fiscal expansions led to unusually large increases in Debt/GDP ratios. However, both the initial levels and the increases in 2020 were not distributed uniformly across country groups. In 2019, at the eve of the crisis, the average debt/ GDP ratio was over $100 \%$ in advanced economies, about $50 \%$ in emerging market and middle-income economies and less than $25 \%$ in low-income developing countries. By mid-2020 the IMF estimated that this ratio will increase by about $15 \%$ in the first two groups and by less than half of that in low-income developing countries during 2020.

The initial differences in levels largely reflect the differences in access to capital markets with advanced economies having the easiest access, the low-income having the poorer, with emerging markets in between. Since they have poor credit ratings, interest on the debt of low-income countries is relatively high and their debt is more difficult to place. Although their need for fiscal expansions is no smaller than that of other countries, low-income countries are limited by their fiscal capacities resulting in smaller increases in debt/GDP ratios during 2020.

Figure 1 displays a map of the worldwide distribution of debt/GDP ratios as of October 2020. The map shows that in major advanced economies such as the USA, Canada, 


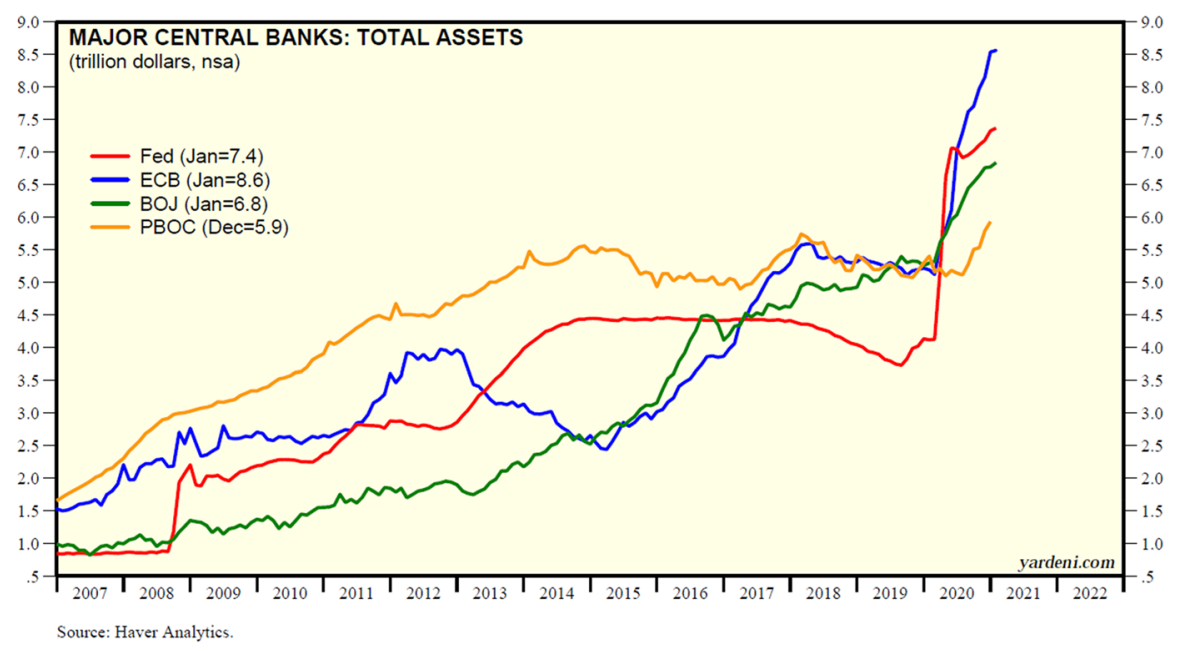

Reproduced from Yardeni Research Inc. (2021), February 15

Fig. 2 Total assets of major central banks. Reproduced from Yardeni Research Inc. (2021), February 15

the UK, Japan, France, Italy and Spain the debt/GDP ratio exceeds $100 \%$, and in India, South Africa and Egypt it is between 75 and 100\%. This ratio is between 50 and $75 \%$ in China, Australia and several European countries, between 25 and $50 \%$ in Chile, Norway, Saudi Arabia and in some African and Asian countries. Russia's Debt/GDP ratio is less than $25 \%$.

In parallel to fiscal measures the CBs of many economies have stepped up open market purchases raising their assets to previously unseen levels. This process was particularly dramatic in advanced economies whose CBs accelerated the use of this instrument and extended the scope of assets purchased.

Figure 2 illustrates the gigantic increases in the assets of the Fed, the ECB and the Bank of Japan, during 2020. The Fed injected huge amounts of liquidity by extending its open operations beyond government debt to include various corporate bonds including bonds with rankings below investment grades as well as stocks. Those operations raised total assets of the Fed from around 4 trillion $\$$ at the beginning of 2020 to 7.4 trillion $\$$ at the beginning of 2021. Similar policies by the ECB raised its assets from over 5 trillion $\$$ to 8.6 trillion over the same period. In parallel the assets of the Bank of Japan increased from over 5.0 trillion to 6.8 trillion. Although not as dramatic the assets of the Peoples Bank of China increased by roughly a trillion $\$$.

Since the introduction of large scale asset purchases during the GFC CBs assets have generally been trending upward. But even against this background the acceleration in the trend during 2020 is a notable outlier. 


\section{Seignorage and the Role of CBs: Past and Present}

Seignorage is the real value of goods and services that the seignorage recipient acquires with new money created by the CB. The huge disruptions caused by the corona crisis and the actual and looming deficits created by extraordinary large fiscal packages led to a recent revival of the view that seignorage should be considered as one of the financing options on the table (Gali 2020a; Yashiv 2020). ${ }^{3}$ This is a dramatic shift from the view that seignorage should never be used which became dominant with the $\mathrm{CB}$ independence revolution. Nonetheless most economists and central bankers strongly oppose such a move for fear that the anti-inflationary institutions erected after long past struggles with inflation will be quickly eroded by governments also during non-crisis times if seignorage is allowed. Friedman (1969) coined the euphemism "helicopter money" or "helicopter drop" to describe a situation in which the CB prints new money and distributes it to the population like mana from heaven. But an helicopter drop of money is only one form of seignorage since the latter can also be used to replace taxes, finance other government expenditures or to reduce reliance on debt issuance. ${ }^{4}$

Institutionally, seignorage can be extracted in one of the following two ways: (i) By law or custom the CB periodically remit parts of its profits to the recipient-usually the ministry of finance; (ii) the $\mathrm{CB}$ credits (directly or indirectly) the account of the recipient against new, zero interest, debt with unspecified maturity date issued to the CB. The first method is used to routinely transfer the Fed yearly profits beyond some level to the US Treasury and by the Swiss National Bank (SNB) to distribute some of its profits to the cantonal governments who own the SNB. Similar arrangements exist in many CBs. The second method has been used to nurture some of the great hyperinflations of the twentieth century. ${ }^{5}$ A well-known case is the post-WWI German hyperinflation during which the CB created new base money by discounting fixed nominal interest governmental bills that were never repaid (Bresciani-Turroni 1937).

It is important to note that under the second method each $\$$ of base money created against government debt issued to the bank is equivalent to a full $\$$ of seignorage only if the debt is never repaid-either because it does not specify a maturity date - or because it is understood that this debt will be frozen in the books of the CB or rolled over indefinitely. I will refer to this case as: full impact seignorage. ${ }^{6}$ But if

\footnotetext{
${ }^{3}$ Caballero (2010) advocated the use of seignorage to finance public infrastructure investments during the early phase of the GFC. Buiter (2014) and Turner (2015) have advocated its use in deflationary environments. Bernanke (2016) discusses some institutional aspects of seignorage but refrains from endorsing its use.

${ }^{4}$ I am indebted to Dirk Niepelt for this distinction. Nonetheless some authors such as Bernanke (2016) use the more dramatic but narrow term "helicopter money" to refer to the broader "seignorage" concept.

${ }^{5}$ In some proposals for the implementation of seignorage the CB finances the government by erasing part of its capital (Galí 2020a; Masciandaro 2020). One drawback of this method is that it is likely to make the CB dependent on fiscal authorities for the replenishment of this capital once the economy is back to normal.

${ }^{6}$ From an accounting point of view, a natural way to record full impact seignorage on the books of the $\mathrm{CB}$ is as a reduction in its capital.
} 
the debt sold to the $\mathrm{CB}$ carries a finite maturity date and pays some interest, and if, come normal times, the $\mathrm{CB}$ is under no obligation to roll it over one $\$$ of government debt sold to the $\mathrm{CB}$ yields less than one $\$$ of seignorage financed by a zero interest perpetuity sold to the bank. Thus, the degree of seignorage involved in purchases of new government debt by the $\mathrm{CB}$ is a continuous variable. It ranges from one (full seignorage) when the zero interest debt is never repaid and tends to zero when the debt is very short term and has to be repaid with a positive rate of interest without any rollovers. Within the intermediate range, the degree of seignorage rises with maturity length and diminishes with the interest rate paid on the debt.

The inflationary experiences of the twentieth century led to the erection of institutional barriers against deficit financing and the financing of deficits by means of seignorage. Those barriers took the form of fiscal rules, central bank independence (CBI) and inflation targeting (IT). ${ }^{7} \mathrm{CBs}$ were given instrument independence in setting short-term interest rates and the monetary base and directed to focus their policies mainly on price stability. Most importantly, CBs were prohibited from lending to government by directly buying new government bonds in order to prevent the use of seignorage by fiscal authorities. ${ }^{8}$ Those institutional measures along with the GFC wiped out inflation altogether. ${ }^{9}$ The traumatic memories of the previous century cemented those institutions to such an extent that they managed to survive even in the face of extended deflationary periods and the associated zero lower bound (ZLB) on interest rates.

\section{Seignorage as a Source of Public Finance within the Theory of Optimal Taxation and the Tradeoff between Implementation of Optimal Taxation and Central Bank Autonomy}

Starting with Ramsey (1927) and Mirrlees (1971) the theory of optimal taxation recommends allocating tax burdens across different tax instruments so as to minimize tax distortions for a given level of government expenditures. ${ }^{10}$ Regular taxes are distortionary for well-known reasons and so is seignorage not the least because of its consequences for the level and the distribution of inflation. Applying this approach to the optimal choice of seignorage Mankiw (1987) proposes and tests a theory in which seignorage is determined along with other taxes in a manner designed to maximize social welfare for a given level of government expenditures. ${ }^{11}$ Once

\footnotetext{
7 A detailed survey of the CBI revolution and its roots appears, among other, in Cukierman (2008).

8 Some limited exceptions are discussed later.

9 However fiscal discipline was not implemented uniformly across countries. As a consequence, different countries entered the corona crisis with substantially different levels of debt to GDP ratios implying different future tax burdens for debt servicing.

10 See also Helpman and Sadka (1979).

11 Mankiw (1987) reports some support for a revenue motivated creation of seignorage. This finding is not as surprising, as might appear at first blush, since the period he investigates is characterized by fiscal dominance. During the early stages of the GFC Caballero (2010) proposed to use seignorage provided it is earmarked for public infrastructural investments.
} 
seignorage is allowed as a legitimate source of funding deficits it should be recognized that, although under current monetary arrangements the CB has full authority to create new money for monetary purposes, it does not possess the authority to engage in seignorage operations since this decision is clearly in the realm of elected legislative and/or executive officials

Since the optimal choice of debt and seignorage finance requires trading off the distortions of future taxes with those of seignorage, this choice has to be made either by a single authority or through coordination of fiscal and monetary policies between fiscal and monetary policymakers. The natural authority for such decisions is the sovereign through democratically elected government officials. This implies that some encroachment on CBI and an increase in fiscal dominance in comparison with the current institutional setting may be necessary in order to allocate deficits financing in an efficient manner between debt and seignorage.

In what follows some ideas to achieve that without reopening the spigot for inflation are explored. As argued in the next section it is mainly relevant for low-income economies and some Latin American governments with limited access to the capital market. It certainly should not be viewed as an endorsement for the use of seignorage by countries with adequate access to financial markets. ${ }^{12}$

When seignorage is considered as part of government's financial package, the main problem is how to optimally allocate deficit financing between new debt and seignorage while assuring that the second source of finance is used only under exceptional circumstances. Bernanke (2016) proposes to achieve this objective by letting the $\mathrm{CB}$ use its base money creation authority to create a new government account that government would be free to use up to a certain limit for financing fiscal expenditures under exceptional circumstance subject to parliamentary or congressional approval. The decision about the total amount in the account would be left to the CB. Within the context of the current crisis Yashiv (2020) proposes a legislated suspension of the prohibition to lend to government by the $\mathrm{CB}$ for ninety days leaving the ultimate decision about the amount of lending to government to the $\mathrm{CB}$ in order not to compromise CBI during normal times.

Interestingly both proposals leave the ultimate decision as to the amount of seignorage finance to the CB. Such an arrangement does not necessarily take into consideration the tradeoffs between debt and seignorage that are crucial for the optimal choice of those two sources of finance. In addition, it saddles the CB with the choice of seignorage which is basically a fiscal decision. It appears therefore that coordination between fiscal and monetary authorities under duress is inevitable. One way to do that would be to consider the enactment of emergency times under which the prohibition to lend to government would be lifted. But the fiscal authorities through the treasury or a similar body would negotiate with the CB the total amount of seignorage to be used for fiscal purposes rather than leave this decision solely to the CB.

\footnotetext{
12 However, in countries such as Japan and the Euro area with persistent deflations and underutilizations of capacity temporary use of seignorage may be indicated to revive economic activity and to lift inflation toward the target.
} 
Another possibility is to create an emergency committee composed of representatives of the Treasury and of the CB and endow it with the authority to choose the amount of seignorage to be created. During the committee deliberations both sides would have to consider both the total amount of funds needed as well as the state of the national debt and its costs. In most developed economies both the Treasury and the $\mathrm{CB}$ have research departments that are well informed about those variables, so their deliberations would be based on a sufficiently broad common ground while still leaving room for useful exchange of information prior to decision. Under this proposal the total amount of fiscal needs would be taken as given by the committee. A possible variant would also endow the committee with some influence on the determination of total fiscal needs.

\section{Deployment of Fiscal Policies during the Corona Crisis and Cross-Country Variations in the Need to Use Seignorage}

The supply and demand disruptions caused by the corona crisis have already prompted many governments to enact large fiscal packages designed to maintain the economy and the health system afloat in the face of workers' confinements, persistent closures of businesses, and mass unemployment. The US 2.2 and 1.9 trillion fiscal package (about 20\% of GDP) discussed in section "Economic Impact of the Corona Crisis and the Response of Aggregate Demand Policies" is one example. The frequent attainment of the ZLB along with the fact that inflation has not been a concern during the last decade and a half imply that fiscal policy and seignorage finance in particular are relatively effective when the ZLB is reached (Galí, 2020b).

Although some economists would agree with Gali (2020a) that the current crisis and circumstances call for reconsideration of the taboo on seignorage, the ultimate conclusion whether to partially rely on it is likely to differ across countries due to different debt-to-GDP ratios along with the associated different interest rates on the public debt. As a consequence, the tradeoff between debt and money finance differs substantially across countries. The upshot is that the optimal combinations of debt and seignorage finance differ across countries. A crucial parameter to watch when deciding whether to use seignorage within a given country, and if so how much, is the elasticity of the demand for the bonds of that country with respect to the interest rate on government bonds

Optimal financing of fiscal deficits implies that countries whose treasuries face lower elasticities will have to rely more heavily on seignorage. If the use of seignorage by countries with low elasticities persists long enough, this may ultimately lead to a divergence of inflation rates across countries. In view of the persistently low world inflation and the anchoring of long-term inflationary expectations this risk appears to be remote at the current juncture. But it should be kept in mind if, following widespread emergency use of seignorage, countries with relatively poor credit ratings decide to engage in relatively persistent seignorage financing. This is most likely to be the case for emerging middle and low-income economies that, as of April 2020, experienced capital outflows of about 100 billion \$ since the beginning of the pandemic. 
The risk of divergent inflation rates due to persistent use of seignorage financing by weaker countries is also important for the Euro area whose CB is committed to maintain a relatively uniform inflation rate across member states. One way to reduce the risk of divergent inflation rates within the Eurozone (EZ) in case monetary financing is tolerated for a while is to centralize the creation of seignorage at the ECB and to distribute the proceeds across countries according to pre-established criteria like GDP and the size of population, or adjust the distributional scheme in a way that would favor weaker countries. ${ }^{13}$

Another option is to engage in some fiscal redistribution across countries. An operational way to implement such a scheme even without explicit use of seignorage is to have the ECB issue Eurobonds and use the proceeds to lend more to the treasuries of countries with relatively poor credit ratings. French president Macron had called for such a scheme, but, unsurprisingly, this was resisted by Germany.

\section{Seignorage Versus Quantitative Easing (QE) and Central Bank Dominance}

With the onset of the GFC QE started to be used on a large scale. It is currently the main monetary instrument used by CBs to address the liquidity and even some of the solvency problems created by lockouts of the work force and forced inactivity in large parts of the economy.

There is an important technical similarity between QE and seignorage in that both are implemented by creating new base money to buy government securities. The main difference between them is that under QE the CB is allowed to buy only seasoned (and possibly other public and private) bonds, whereas under seignorage the $\mathrm{CB}$ is allowed to buy new public securities at source providing direct financing to government. Thus QE is a device that enables CBs to ease government finance subject to the so-called no printing precondition for CB autonomy. Although it does not involve direct financing of the deficit, QE supports government finances by assuring a smooth market for seasoned government bonds and the associated reductions in the cost of new issues.

In this sense QE is a weaker form of full impact seignorage for two reasons. First QE does not necessarily induce additional government expenditures, while seignorage is by definition new money spent by government for goods, services and transfers. Second, even when QE facilitates at the margin funding of larger government expenditures they most likely are lower than the expenditures financed by a similar amount of full impact seignorage since the bonds purchased to sustain QE are expected to necessitate future taxes in order to be repaid along with (usually) positive interest. ${ }^{14}$

\footnotetext{
${ }^{13}$ Currently the actual distribution of the ECB profits is based on the capital key that gives equal weights to GDP and population.

${ }^{14}$ Admittedly, some of the interest payment may be refunded to government through profit transfer schemes. However, under existing monetary institutions there is not always a one to one correspondence
} 
As is the case with less than full seignorage the stimulatory impact of $\mathrm{QE}$ is larger the longer the assets purchased to implement it are held by the CB. Interestingly, to this day the Fed still holds a substantial amount of assets created during the GFC and its aftermath. Just prior to the onset of the corona crisis the balance sheet of the Fed was in the vicinity of 4 trillion $\$ .{ }^{15}$ Following the massive QE operations recently deployed in reaction to the shrinkage of economic activity due to the corona virus the balance sheet reached 7.4 trillion \$ in January 2021 (Fig. 2).

By extending QE operations to long-term maturities during the GFC the Fed managed to influence the level and slope of the yield curve. Similarly, by relieving some of the pressure on the supply of bonds by government seignorage can lower the yield curve and extend the range of maturities that government can borrow at. Hence it is also likely to flatten the governmental yield curve and ease the access of corporation and households to credit. Generally, both QE and seignorage may have permanent or temporary effects on the monetary base depending on whether the $\mathrm{CB}$ decides to maintain the monetary base that was created by those operations in the future. As with QE operations CBs may or may not decide to roll government obligations purchased with the additions to the monetary base resulting from less than full impact seignorage financing. Due to institutional reasons it is less likely that seignorage operations will be reversed by the $\mathrm{CB}$ through open market sales at some point in the future than is the case for QE operations. Assuming that the public is aware of this difference this reinforces the relative stimulatory impact of fiscal expenditures financed by seignorage through public beliefs in comparison with debt financing.

In summary, an important advantage of QE over seignorage is that it can be deployed within the existing framework of CBI and inflation targeting. On the other hand, it's stimulatory impact per $\$$ is usually lower than that of seignorage. An interesting question for future research is how many $\$$ of $Q E$ are required to achieve a stimulatory impact identical to one $\$$ of seignorage.

Be that as it may, it appears that major advanced economies such as the USA, the Euro area, Japan and the UK opted to use QE on very large scales as substitutes for the potential use of seignorage. The implicit thinking behind this choice is that it is preferable since it can be implemented without relaxation of the taboo on explicit monetary financing. The view underlying this choice is probably that similar impacts on liquidity and on the ability of government to manage and service larger public debts can be achieved by larger and more persistent doses of QE.

It is useful to point out at this point that even in the presence of formal CBI government can influence the amount of liquidity in the economy through changes in its deposits with the CB. A striking example is the US Treasury General Account (TGA) with the Fed. Running down the balance of this account by the Treasury has

\footnotetext{
Footnote 14 (continued)

between the two. In addition, be that as it may, the principal always must be repaid by government unless the $\mathrm{CB}$ decides to roll the debt indefinitely.

15 Just prior to the onset of the GFC the Fed's balance sheet was about a fifth of this figure. Details appear in Cukierman (2019).
} 
the same impact on liquidity in the economy as a QE operation and building this balance up is equivalent to an open market sale by the CB. The TGA balance peaked at 1.8 trillion $\$$ in July 2020 and is currently projected to decrease by over a trillion during the first half of 2021. Thus, even under existing institutional arrangements part of QE policies are under direct control of the Treasury.

This section concludes on an historical note. QE like operations were conducted by the Fed long before the GFC but under a different label in order to support public finances. The USA emerged from WWII with a debt-to-GDP ratio of about $120 \%$. Between the end of the war and 1951 one of the main policy objective of the Fed was to support the price of seasoned government debt in order to maintain a low interest cost to government and prevent capital losses to holders of this debt. This arrangement known as the "Accord" was implemented by the Fed buying seasoned governmental securities when their price would have decreased otherwise [details appear in Meltzer (2003)]. In modern terminology this was a standing QE operation aimed at facilitating public finances. However, it is important to note that $\mathrm{QE}$ under the accord was dictated to the CB by the political authorities, whereas the modern $\mathrm{QE}$ operations are under the discretion of the CB.

\section{Should Seignorage be Used in View of the Current Inflation Outlook?}

Given current information (March 2021) it is not evident that the unusually large fiscal and monetary responses to the economic crisis in major advanced economies carry serious inflationary risks. The reason is that the huge original shocks to both aggregate supply and demand triggered by the crisis operate in mutually opposite directions. The reduction in the price of oil and other commodities as well as solid anchoring of long run inflationary expectations during 2020 operated in the same direction, but, as of March 2021, the price of oil has recovered to some extent. In the USA two huge fiscaI packages and a revival of economic activity have lifted short-run inflationary expectations to around 3\%, but long-run expectations are well anchored a bit above the $2 \%$ target. In the Euro area expectations are anchored well below the $2 \%$ standard target. Some forecasters even predict that, in the absence of additional stimulus the outlook for the Euro area is deflationary rather than inflationary.

It appears that under such circumstances the inflationary risk of financing limited parts of the deficits by means of seignorage is moderate. It is nonetheless prudent to also consider policy options in case persistent use of seignorage leads to unanchoring of inflationary expectations on the upside. Given the behavior of inflationary expectations during the last decade this risk appears remote for advanced economies at the current juncture. Relatedly, Blanchard and Pisany-Ferri (2020) note that there is no evidence that CBs have given up on their price stability mandate in spite of huge QE operations undertaken in the US and other advanced economies. At the beginning of April, the UK Treasury and the Bank of England (BoE) agreed on a limited direct credit line from the $\mathrm{CB}$ to the Treasury in order to alleviate short run pressures in the bond market. But the April 9 joint press release by the $\mathrm{BoE}$ and her 


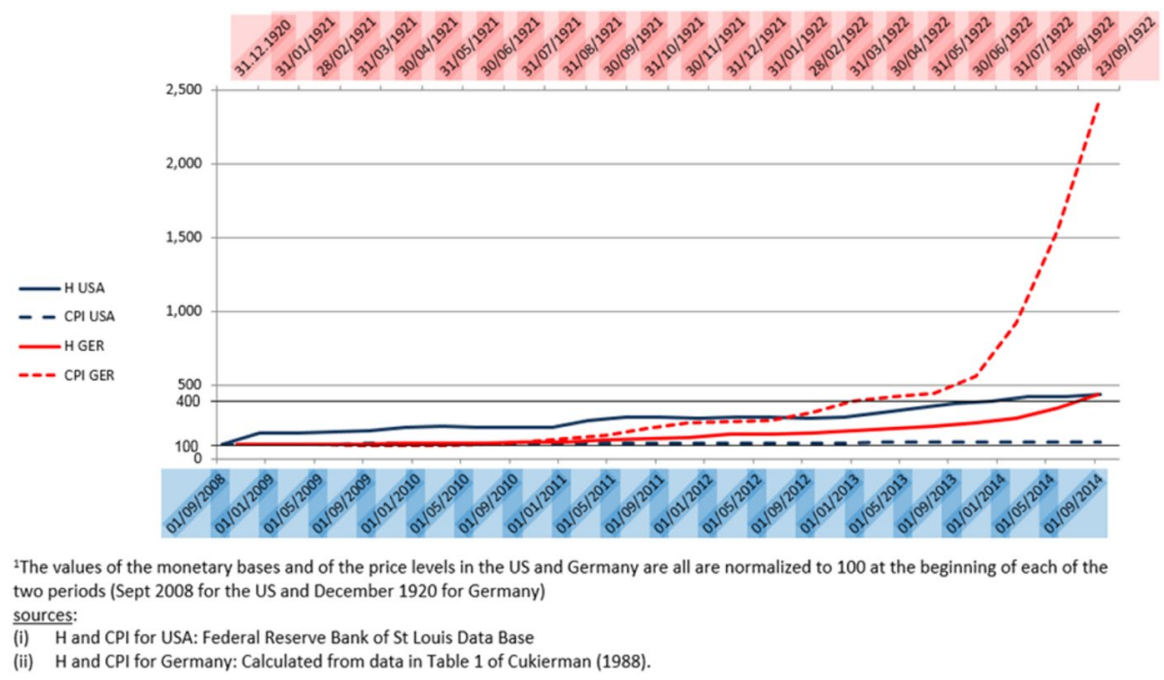

Fig. 3 The behavior of monetary base and the price level in the USA since Lehman's collapse and during the German hyperinflation: a comparison

majesty Treasury explicitly states that any use of the direct financing scheme will be short term and temporary.

Nonetheless in case seignorage becomes a legitimate but temporary source of finance in some countries this is a risk that should be recognized. In addition, price adjustments will not remain the same for two reasons. First supply shortages will lead to some price increases. But those are largely self-limiting and do not necessarily cause permanent inflation unless supply deteriorates continuously. On the side of demand large liquidity and reserve injection may stimulate lending. But this is offset by large uncertainty about the duration of the crisis and the effectiveness of vaccination campaigns.

On the other hand, for countries with limited access to capital markets the inflationary risks of seignorage finance are substantial. Such countries rely on seignorage for lack of other options. Argentina is an extreme example along this spectrum. During 2020 it financed most of its $7 \%$ primary deficit by means of money creation for lack of other options such as debt relief (inflation was almost 54\% in 2019 and 36\% in 2020).

But, for regions like the Eurozone (EZ) and Japan, in which deflation rather than inflation is a problem some temporary reliance on seignorage financing is desirable not only because of optimal taxation considerations but also because it can lift inflation toward the target more effectively than QE operations. The relative advantage of a $\$$ of seignorage over a $\$$ of $Q E$ is illustrated in Fig. 3 [reproduced from Cukierman (2017)] by means of a comparison of rates of inflation in the USA during the six years following Lehman's downfall with a bit over half of the post-WWI German hyperinflation for identical cumulative rates of base money expansion.

Base expansion took the form of direct monetary financing of government in Germany and the form of QE in the USA. Since in both episodes the cumulative rate of 
base expansion is the same, the figure provides an indication of the relative potency of seignorage versus QE in generating inflation. Note that the solid lines indicate the levels of the monetary bases and the broken lines the price levels in the two countries. USA and German data are marked in blue and red, respectively.

The comparison in the figure shows that: (1) after a while seignorage induces substantially higher inflation than QE. (2) In the initial phases of German seignorage expansion inflation lags behind base expansion and picks up dramatically only after a period of almost a year as initially lagging inflationary expectations and the speed of price adjustment rise (further details appear in Cukierman (2017). (3) By contrast in the USA, during the six years of substantial QE operations following Lehman's downfall inflation stagnated.

In interpreting those results it should be kept in mind that the QE operations of the Fed were conducted under CB dominance cum inflation targeting while the seignorage operations of the Reichsbank during the German hyperinflation were directly dictated by government. Obviously, anchoring of expectations in the second case was inexistent - $\mathrm{a}$ fact that contributed to a dramatic acceleration of inflation once those expectations started to catch up with actual inflation.

In addition, there also is a substantial difference in the behavior of the narrow money supply between the two episodes. In the USA the money supply increased much less than the monetary base as the banks refrained from using their large excess reserves to increase credit (Cukierman 2019, Figure 7). In Germany practically all the increase in the monetary base took the form of an increase in narrow money since government quickly used the new funds to finance its budget (Bresciani-Turroni 1937).

The hyperinflationary experiences of Germany and other countries during the first half of the twentieth century contributed a lot to the current institutional taboo on using seignorage. They convincingly demonstrated the havoc that uncontrolled use of seignorage by short-sighted dominant fiscal authorities can do. But, as argued above, at the current juncture, appropriately limited seignorage can be beneficial for some countries for more than one reason. In such a case preannouncement of a limited period for the duration of partial direct monetary financing is probably the most effective measure against an upward unanchoring of expectations.

But, even if the severity and duration of the corona crisis extends the period of seignorage finance beyond prior plans in some countries, policymakers always have the option to terminate it should upward unanchoring of expectations turn out to be a serious problem. The evidence from the post-WWI German inflation suggests that following a period of relative price stability inflation expectations lag behind initially accelerating inflation and seignorage expansion leaving enough time for policymaker to take corrective action should the need arise. 


\section{Concluding Remarks}

The inflations, hyperinflations and deficits of the twentieth century led to the central bank independence (CBI) revolution along with a taboo on seignorage as well as restrictions on government expenditures, deficits and debt to GDP ratios. ${ }^{16}$ The severe economic impact of the corona crisis led policymakers to ignore fiscal restrictions and deploy extraordinarily large fiscal packages leading to huge deficits and large actual and prospective increases in debt/GDP ratios. CBs contributed to this effort by engaging in large QE operations.

To date those policy responses strictly adhered to the existing taboo on seignorage to finance deficits. This taboo, which is one of the pillars of CBI, has served the world well by providing an effective nominal anchor against inflation during normal times following the demise of the Bretton-Woods system. But current circumstances are substantially different than forty years ago when the main concern was inflation and the absence of a nominal anchor. First, inflation has not been a concern for over a decade. As a matter of fact, in the Euro area and Japan deflation is currently a main concern. Second, there is evidence that, when the ZLB is binding, fiscal expenditures financed by seignorage are particularly effective in stimulating the economy (Galí 2020b).

Last, but not least, the current huge budgetary financing needs call for a temporary use of a wider set of funding instruments. By contributing funds to deficit financing seignorage alleviates some of the burden on future generations and moderates the increase in the cost of debt that would occur otherwise. As a matter of fact, optimal taxation theory implies that deficits should be financed by both debt and seignorage implying, at first blush, that this is a matter that falls entirely within the realm of fiscal authorities (section "Seignorage as a Source of Public Finance within the Theory of Optimal Taxation and the Tradeoff between Implementation of Optimal Taxation and Central Bank Autonomy"). The downside is that this infringes on CBI cum inflation targeting creating a potential tradeoff between optimal taxation and the safeguard of price stability by short-sighted politicians.

The paper has explored a number of schemes designed to allow temporary lifting of the taboo on seignorage during emergency times while preserving full institutional independence of the CB in normal times. A common thread of those schemes is to assure cooperation between fiscal and monetary authorities to achieve the goal of efficient public financing of stimulatory fiscal packages during extreme downturns without opening the spigot for use of seignorage during normal times. One possibility is to have a joint committee of fiscal authorities and the $\mathrm{CB}$ decide whether economic circumstances justify lifting of the taboo, and if so, on the allocation of deficits between debt and seignorage. In some cases, this cooperation can be achieved without the creation of a formal institution ${ }^{17}$.

\footnotetext{
${ }^{16}$ Details appear, among other, in Cukierman (1998).

${ }^{17}$ In the USA, Secretary of the Treasury Mnuchin and Fed's Chair Powell coordinated their actions through numerous informal daily consultations.
} 
The need to use seignorage varies across countries inversely with their access to capital markets, their initial debt-to-GDP ratios and the interest elasticity of demand for their sovereign debt. Thus, while seignorage is likely to be unnecessary for the likes of USA and Germany, it is essential for poor- and middle-income countries whose access to international capital markets has been restricted in the first place and experienced a further deterioration with the onset of the crisis. It is also likely to be essential for some countries within the Euro area with poor credit ratings such as Italy and Spain. This heterogeneity within the Euro area complicates the task of the ECB.

Both QE and seignorage are implemented by increasing the monetary base. The main difference between them is that under QE the CB buys only seasoned government obligation, whereas under seignorage it can also buy them at source. QE eases government finances by maintaining a market for government bonds but less than an equivalent amount of full impact seignorage since QE operations are associated with expected future taxes while full impact seignorage is not. For the same reason, the inflationary impact of seignorage is stronger than that of QE. However, given the currently depressed level of aggregate demand allowing temporary seignorage financing does not appear to carry a major inflationary risk. As a matter of fact, it may help lift the negative or extremely low inflation rates in some countries toward the inflation target.

By inducing hefty increases in the value of financial assets the large QE operations deployed during the global financial crisis created an artificial disconnect between financial markets and the real economy (Capelle-Blancard and Desroziers 2020). It also reinforced a long run trend of rising inequality in the distribution of wealth. ${ }^{18}$ There is little doubt that the, even larger, QE operations that have already been deployed to date during the pandemic, augmented by upcoming ones, will reinforce those trends. Other things the same, a largely overlooked side benefit of financing part of budgetary deficits by seignorage rather than by QE is that it moderates the disconnect between financial markets and the real economy, and mitigates the increase in the distribution of wealth induced by QE.

\section{References}

Bernanke, B. 2016. What tools does the Fed have left? Part 3: Helicopter money. Brookings, April. https://www.brookings.edu/blog/ben-bernanke/2016/04/11/.

Blanchard, O., and J. Pisany-Ferri. 2020. Monetization: do not panic. VoxEU, April https://voxeu.org/ article/monetisation-do-not-panic.

Bresciani-Turroni, C. 1937. The economics of inflation: a study of currency depreciation in post war Germany. London: George Allen and Unwin Ltd., New York: William Salloch.

Buiter W. 2014. The simple analytics of helicopter money: why it works-always. Economics. https://doi. org/10.5018/economics-ejournal.ja.2014-28

Caballero, R. 2010. A helicopter drop for the US Treasury. VoxEU. https://voxeu.org/article/helicopterdrop-us-treasury.

${ }^{18}$ In the USA households with incomes below the median have hardly any financial assets and the top 10 percent own 70 percent of US wealth. 
Capelle-Blancard, G., and A. Desroziers. 2020. The stock market is not the economy? Insights from the COVID-19 crisis. CEPR Covid Economics 28: 29-69.

Cukierman, A. 1998. Central bank strategy, credibility and independence: theory and evidence. Cambridge: The MIT Press.

Cukierman, A. 2008. Central bank independence and monetary policymaking institutions_-past, present and future. European Journal of Political Economy 24: 722-736. https://www.tau.ac.il/ alexcuk/ pdf/Published\%20Version-POLECO1087.pdf.

Cukierman, A. 2017. Money growth and inflation: policy lessons from a comparison of the US since 2008 with hyperinflation Germany in the 1920s. Economic Letters 154: 109-112. https://www.tau. ac.il/ alexcuk/pdf/Cukierman\%202017.pdf.

Cukierman, A. 2019. A retrospective on the subprime crisis and its aftermath ten years after Lehman's collapse. Economic Systems 43(3-4): 100713. https://doi.org/10.1016/j.ecosys.2019.100713.

Data Base of Fiscal Policy Responses to Covid19. 2021. IMF, January. https:/www.imf.org/en/Topics/ imf-and-covid19/Fiscal-Policies-Database-in-Response-to-COVID-19.

Fiscal Monitor. 2020. IMF, October. https://www.imf.org/en/Publications/FM/Issues/2020/09/30/october2020-fiscal-monitor.

Friedman, M. 1969. The optimum quantity of money. In The optimum quantity of money and other essays, ed. M. Friedman. Chicago: Aldine Press.

Galí, J. 2020a. Helicopter money: the time is now. VoxEU, March. https://voxeu.org/article/helic opter-money-time-now.

Galí, J. 2020b. The effects of a money-financed fiscal stimulus. Journal of Monetary Economics 115: $1-19$.

Gourinchas, P.O. 2020. Flattening the pandemic and recession curves. In Mitigating the COVID economic crisis: act fast and do whatever it takes, ed. R. Baldwin and B. WederdiMauro. A VoxEU.org Book, CEPR Press.

Helpman, E., and E. Sadka. 1979. Optimal financing of the government's budget: taxes, bonds, or money? The American Economic Review 69(1): 152-160.

Mankiw, G. 1987. The optimal collection of seignorage: theory and evidence. Journal of Monetary Economics 20: 327-341.

Masciandaro, D. 2020. Covid-19 helicopter money: economics and politics. Covid Economics 7: 23-49.

Meltzer, A.H. 2003. A history of the federal reserve, Volume I: 1913-1951. Chicago: University of Chicago Press.

Mirrlees, J. 1971. An exploration in the theory of optimum income taxation. The Review of Economic Studies 38(2): 175-208.

Ramsey, F. 1927. A contribution to the theory of taxation. The Economic Journal 37(145): 47-61.

Turner, A. 2015. The case for monetary finance-an essentially political issue. In 16th Jacque Polak Annual Research Conference. IMF.

World Economic Outlook Update. 2021. IMF. https://www.imf.org/en/Publications/WEO/Issues/2021/ 01/26/2021-world-economic-outlook-update.

Yardeni Research Inc. 2021. Central Banks: Monthly Balance Sheets, February 15. https://www.yardeni. com/pub/peacockfedecbassets.pdf.

Yashiv, E. 2020. Breaking the taboo: the political economy of COVID-motivated helicopter drops. VoxEU, March. https://voxeu.org/article/political-economy-covid-motivated-helicopter-drops.

Publisher's Note Springer Nature remains neutral with regard to jurisdictional claims in published maps and institutional affiliations. 